\title{
Fillers Used by English Department's Students of State University of Medan
}

\author{
Nadya Nurfadilah ${ }^{1, *}$ Ani Holila Pulungan ${ }^{2}$ Amrin Saragih ${ }^{3}$ \\ ${ }^{1,2,3}$ Post Graduate School of Applied Linguistics Study Program, Universitas Negeri Medan, Medan, Indonesia \\ *Corresponding author. Email: nadyanurfadilah22@gmail.com
}

\begin{abstract}
Society does not only need to develop linguistic competence but also appropriate communicative competence in communicating foreign languages. Speaking foreign languages is not easy, sometimes people pause during speaking. In fact, many spontaneous speakers of various languages have pauses in speaking that are taken when needed. This phenomenon is commonly called a filler. The objective of this research to evaluate reasons for the use of fillers by English department's students. This research was conducted by descriptive qualitative design as methodology of research. The data are fillers used by English departments's students in the form of the lexical empty (sound), words and phrases. The researcher as the key instrument is voice recorder. The result of this research found All the functions in this research used by English department's students, they were hesitating (16 times), empathizing (11 times), editing term (14 times), mitigating (4 times) and time-creating (5 times).
\end{abstract}

Keywords: Pragmatic, Filler, Speaking.

\section{INTRODUCTION}

Language is a tool for interaction in daily conversation. Bickerton states that language is tool of communication whereas human intelligence is the result of rapid growth and the unusual size of the human brain $^{\{1\}}$. This means that communication and language are two components that cannot be separated from humans. Learning to speak a second language (SL), especially a foreign language (FL) is not as simple as possible. Because speaking foreign languages is not easy, sometimes people pause during speaking. In fact, many spontaneous speakers of various languages have pauses in speaking that are taken when needed ${ }^{[2]}$. This phenomenon is commonly called a filler.

Filler as a break in the flow of $\operatorname{speech}^{[3]}$. Most people produce fillers in their spoken interactions. Here are a few examples of preliminary data

Student 1 : Ok, thank you moderator, as you know, our topic discussion is poetry. Uh, I will introduce our group first.

The preliminary data showed that filler used in his speaking. There are unlexicalized filled pause "Uh" and lexicalized filled pause "ok" and you know. The occurrence of the field "ok" is pronounced in the boundary or first sentence, The use of "ok" In the utterences above, indication to open conversation. It was not placed at its primary function. As we know that the function of "ok" is to show an agreement. The occurrence of the field "you know" is pronounced in the middle, the phrase "you know" is a lexicalized pause, meaning as an editing term, cause to take control of the conversation and as the speaker thinks about what to say next. The occurrence of the field "uh" is pronounced in the last sentence (later), The use of "uh" in the sentence was followed by a delay for about 2 seconds. It implied that the speaker needed sometimes to think about what word to be started and the speaker needed more time to decide what to say. Here are a few examples of preliminary data with the different student.

This situation triggers researchers to conduct research on Fillers Used by English Department's Students of State University of Medan to evaluate reasons for the use of fillers by English department's students.

The scope of this study is limited to the subject matter of fillers and the utterances uttered by English department's students devided into one classroom from applied linguistic and one classroom from English education department of state university of Medan which are common or appear in learning process.

\subsection{Pragmatics}

Pragmatics is the study of how to do things with words and the meaning of language in context. On the other hands, in understanding utterences we have to look at the context because the meaning of what is said depends much more on the context and its intended meaning. 


\subsection{Filler}

Filler is the moment when someone stops the conversation to think what they want to say without giving the impression that we finish our conversation. In daily conversation, people often use uh, uh, um, ah, um, yeah I mean, you know, or something similar. This kind of speech is called filler ${ }^{[4]}$. He also describes fillers as sounds or words or phrases that can appear anywhere in speech and can be removed from speech without a change in content.

\subsection{Functions of Filler}

There are at least five functions of fillers which will be explained further. They are hesitating, empathizing, mitigating, editing term, and time-creating devices ${ }^{[4]}$.

\subsection{Hesitating}

Hesitation is pause which increase in the place of a sentence when the speaker has a difficult decision to use words, this function of filler occurs when the speaker must to stop and think about what he / she is going to say next and when he / she is making a sentence together ${ }^{[5]}$. Most filled pauses (ee, em, err, uhm, ah, hm, etc) are used as breathing pauses, such pauses generally fit the semantic syntactic limits.

\subsection{Empathizing}

Filler can define as an invitation for listeners to be involved in the speaker's words ${ }^{[6]}$. An example of filler is the intention of being aempathizing purposes are well, you know, hey and so on.

\subsection{Mitigating}

Fillers mitigate utterances so as not to hurt the the addressee's feeling ${ }^{[4]}$. Fillers as like well, um, er, and okay can serve as mitigating or politeness devices.

\subsection{Editing Term}

Fillers are used to correct speech errors of speakers $^{[4]}$. I mean, um, uhm, $\boldsymbol{u h}, \boldsymbol{h u h}, \boldsymbol{e e}, \boldsymbol{e t c}$ can show the speaker's awareness of speech errors, the speaker replaces certain old words with new ones, so it shows that old words have been misplaced.

\subsection{Time-Creating}

Common from filler is used as a time-creating tool in lexical repetition ${ }^{[6]}$.

\subsection{Speaking}

Speaking is a productive skill that can be directly and empirically observed, those observation are invariably colored by the accuracy and effectiveness of a test-takers listening skill, which necessarily compromises the reliability and validity of an oral production test ${ }^{[7]}$. It means that when we speak something it can be directly measured by listener.

\subsection{Online Learning}

Online learning encompasses a range of technologies such as the worldwide web, email, chat, new groups and texts, audio and video conferencing delivered over computer networks to impart education ${ }^{[8]}$.

\section{METHOD}

This research conducted descriptive qualitative design as methodology of research. Descriptive qualitative method is the method that emphasized to the meaning and description of certain condition (in certain context) which is used in daily life. Qualitative research has the natural setting as the direct source of data. It means that qualitative research has the natural setting as the direct source of data ${ }^{[9]}$. It means the qualitative research is the study things in their natural settings, attempting to make sense in terms of the meaning people bring to them. Related to the study, the researcher do not do anything with the object of the study. The researcher only finds out why the phenomenon happen.

The data are fillers used by English departments's students in the form of the lexical empty (sound), words and phrases. The sources of the data are English department's students devided into one classroom from applied linguisticand one classroom from English education department of state university of Medan.

\section{RESULT AND DISCUSSION}

Table 1. The function of Fillers Used by English Department's Students

\section{Function of Fillers}

Hesitating Empathizing Mitigating Editing Term Time-Creating

\begin{tabular}{lllll}
\hline 16 & 11 & 14 & 4 & 5
\end{tabular}

Based on the table above, it showed that English department's students used fillers functioned as hesitating was dominant, because occurred 16 times, than as empathizing occurred 11 times, editing term occurred 14 times, mitigating occurred 4 times and time-creating occurred 5 times.

For complete analysis of the function of fillers used by English department's students, had been in the follow:

\section{Hesitating}

Hesitations are pauses which increase in the places of a sentence when a speaker has difficult decision in using the words, these function of fillers occur when the speaker must stop and think about what he/she will say next and when he/she is putting a sentence together ${ }^{[5]}$. Most of filled pauses (ee, em, err, uhm, ah, hm, etc) are used as the breathing pauses, such pauses generally match semantic-syntactic boundaries. 


\section{Data 1 (English education)}

"hmm... okay. If you drink your coffee later".

Based on data 1 above, the filler "hmm" used by English department's students to hesitate the speech and think what would say next. Because before say the filler "hmm" the speaker stated their sentences fluently then stated the filler "hmm" then stop and think what would say next. So, in this data the function of filler is as hesitating.

\section{Data 2 (applied linguistic)}

“what happened Lyra?,hmm... are you ok?”.

Based on the data 2 above, the filler "hmm" used by English department's students when talking with their friend said "what happened Lyra?" then continuous by filler "hmm" and continuous again with the sentences relate to sentences before filler "hmm". It showed that filler "hmm" here functioned as hesitating, because the English department's students used that filler to think what will they say next.

\section{Empathizing}

The speaker can use filler as attention-getting device. It means that the speaker can check whether the listener pays attention or not. Based on,fillers define as an invitation for the listener to be involved in what the speaker says ${ }^{[6]}$. The example of fillers as empathizing purposes are well, you know, right, hey and so on.

\section{Data 1 (English education)}

"It's an amazing Sunday, isn't it?"

Based on data 1 above, the filler "isn't it" was functioned as empathizing because the speaker say their utterances and then empathize with filler "isn't it" to get the attention from the listeners.

\section{Editing Term}

The editing term is also one of the filler functions. Filler are used to correct the speech errors in the utterances' speakers ${ }^{[4]}$. In the other word, the speaker is aware if she/he makes a speech error. The she/he wants to correct it.

\section{Data 1 (English education)}

"I mean this is serious.

Based on the data 1 above, the filler used and functioned as editing term because filler "I mean" to correct the speech to the right words, so it is function as editing term.

\section{Data 2 (applied linguistic)}

"Sorry, not today but next meeting"

Based on the data 2 above, it showed that the filler "sorry" is functioned as editing term, because when using the filler, the speaker was correcting the word into the right word. It means edited the term.

\section{Mitigating}

Fillers can also serve as mitigating devices, Fillers mitigate utterances so as not to hurt the addressee's feeling ${ }^{[4]}$. The function of fillers because the face need to feel liked (positive face needs) or politeness devices.

\section{Data 1 (English education)}

"Okay, from now I will learn seriously".

Based on the data 1 above, the filler used and functioned as mitigating because filler "okay" to protect face needs is an important function of fillers because the face need to feel liked (positive face needs).

\section{Data 2 (applied linguistic)}

“Okay, sorry. I will do it now".

Based on the data 2 above, the filler used and functioned as mitigating because filler "okay" to show politeness devices.

\section{Time-Creating}

Fillers can also be used as a means of creating time. The filler gives the speaker time to think about what to say next. Common from filler is used as a time-creating tool in lexical repetition ${ }^{[6]}$

Data 1 (English education)

"yeah, yeah it's true"

Based on the data 1 above, the filler used and functioned as time-creating because filler "yeah", the speaker repeats one word in turn to give the speaker time to plan what to say next.

\section{Data 2 (applied linguistic)}

\section{"I think, I think she is right"}

Based on the data 1 above, the filler used and functioned as time-creating because filler "I think", that common from filler is used in lexical repetition. All the repetitions in pronunciation serve as filler to give the speaker time to plan what to say next.

All the function found in this research used by English department's students, they were hesitating, empathizing, and editing term, mitigating and timecreating. English department's students used fillers functioned as hesitating because when they talk to their friend because when sometimes English department's students didn't attend by the audiences, they will empathizing their speech by using fillers. And sometimes the English department's students said wrong speech then they edit their speech by using filler. Filler used and functioned by English department's students as mitigating because to show politeness devices. Filler 
used and functioned by English department's students as time-creating because speaker repeats one word in turn to give the speaker time to plan what to say next.

\section{CONCLUSION}

There were five functions of filler used by English department's students in talking with their friend. They were hesitating, empathizing, editing term, mitigating and time-creating. English department's students used fillers just functioned as hesitate their words, empathizing their word aimed to get the attention by the listener, as editing term to edited their words when said the wrong and edited in to right words. Filler used and functioned by English department's students as mitigating because to show politeness devices.Filler used and functioned by English department's students as timecreating because speaker repeats one word in turn to give the speaker time to plan what to say next.

\section{REFERENCES}

[1] Bickerton, D. (1995). Language and Human Behavior. Washington: University of Washington Press.

[2] Erten, S. (2013). Teaching Fillers and Students' Usage : a study conducted at ESOGU preparation school.

[3] Yule. (2006). The Study of Language. Cambridge : Cambridge University Press

[4] V, Baalen. (2001). Male and female Language: Growing together.

[5] Wu, J. (2001). A Quantitative Comparison of Disfluencies Types between Native and Non-Native English Speaker in Spontaneous Speech

[6] Stenström, A. (1994). An Introduction to Spoken Interaction. London: Longman.

[7] H. Douglas Brown, (2004) Language assessment principle and classroom practice (New York: Pearson Education), 140-141

[8] Dhull, Indra and MS. Sakshi. (2017). Online Learning. International Education \& Research Journal [IERJ] E-ISSN No : 2454-9916 Volume. 3 Issue 8. Rohtak: Haryana.

[9] Bogdan, R. C and Biklen, S. K. (1982). Qualitative research for education: An Introduction to Theory and Methods. Boston: Allyn and Bacon, Inc. 